\title{
Influence of the Size of Potato Microtubers (Solanum tuberosum L.) on the Yield of Plants under Semi-Axenic Conditions
}

\author{
Abraham Diémé, Oumar Ba, Maurice Sagna, Mame Ourèye Sy* \\ Laboratoire Campus de Biotechnologies Végétales, Département de Biologie Végétale, Faculté des Sciences \& Techniques, \\ Université Cheikh Anta Diop, BP 5005, CP 10700, Dakar-Fann, Sénégal \\ Email: *oureye.sy@ucad.edu.sn
}

How to cite this paper: Diémé, A., Ba, O., Sagna, M. and Sy, M.O. (2021) Influence of the Size of Potato Microtubers (Solanum tuberosum L.) on the Yield of Plants under Semi-Axenic Conditions. Advances in Bioscience and Biotechnology, 12, 65-77. https://doi.org/10.4236/abb.2021.123005

Received: February 4, 2021

Accepted: March 22, 2021

Published: March 25, 2021

Copyright $\odot 2021$ by author(s) and Scientific Research Publishing Inc. This work is licensed under the Creative Commons Attribution International License (CC BY 4.0).

http://creativecommons.org/licenses/by/4.0/

\begin{abstract}
The potato (Solanum tuberosum L.) is a vegetable that ranks fifth in the world for human consumption. Its importance is growing more and more in the Senegalese diet. However, the potato production in Senegal does not meet the needs of the market, which maintains dependence on the outside for the supply of quality seeds. In addition, these imported seeds do not often have phytosanitary qualities required for local production in the Sahelian zone. The in vitro production of microtubers, used as seed, has been shown to be one of the most efficient means for propagation of basic material. To overcome the constraints linked to the supply and availability of potato seeds, with high germination capacity, the impact of the microtuber size on the yield of the plants under semi-controlled conditions was examined. The pre-germinated microtubers were produced in vitro from vitroplants of 3 different varieties (Aida, Atlas, Odessa) adapted to the edaphic-climatic conditions of Senegal. The effects of the seed sizes of microtubers, greater than $4 \mathrm{~mm}$, sown under semi-controlled conditions, on the yield of the plants, result in an increase in the ratio, in the vegetative development of the plants, but also in the number and size of the minitubers harvested. The yield of the plants also depends on the variety. It can therefore be envisaged to produce local potato seeds from microtubers and minitubers.
\end{abstract}

\section{Keywords}

Solanum tuberosum, Microtubers, Germination, Seed Size, Yield, Minitubers

\section{Introduction}

Senegal is a Sahelo-Sudanese country whose major climatic features result from 
the conjunction of geographic and aerological factors. Due to its geographical position on the African continent and its western limit by the Atlantic Ocean, it has a North Atlantic coastal fringe. This one extends from the Cape Verde peninsula to the delta of the Senegal River for approximately $195 \mathrm{~km}$ long. This coastal zone benefits from a flow under particular climatic conditions. This is represented by the maritime trade wind from the Azores high pressure north to northeast. The maritime trade winds are constantly humid, cool and even cold at night in the dry season, and marked by low diurnal thermal amplitude. It is at this coastal fringe that the cultivation of potatoes is mainly done in a sandy interdune area called the "Niayes", from November to June [1].

The potato sector is booming in Senegal. In 2011, production was 12,000 tons of potatoes and 118,000 tons in 2017. Officially, potato production in 2019/2020 is 178,175 tons while in 2016 , production is assessed to 67,485 tons; which would correspond to 4 and a half months of consumption. This positive increase in the areas sown for this horticultural speculation, places the country among the 5 largest suppliers of starch in the West African sub-region. The two main production basins, in Senegal, seem to be Kayar and Mbane with potentials estimated at 80,000 and 60,000 tons, respectively. The good results of the harvests of recent years can be explained by the increase in the annual national subsidy for the acquisition of potato seeds, which rose from 130 million CFA francs in 2013 to 3.4 billion 400 million in 2018, i.e. 500 tons of seeds subsidized by the State in 2013 against 10,444 t in 2018. The main constraint for producers is the lack of a tuber storage and conservation store for a long time. This is a problem that persists in the horticultural sector. The other major problem to be solved for the potato sector concerns the availability of local certified seeds. Thus, the FAO confirms that Senegal imported $43,417 \mathrm{t}$ of potatoes in 2018 ( $8^{\text {th }}$ importing country in Africa) and the state constantly subsidizes the purchase of imported seeds.

The potato (Solanum tuberosum L.) is a perennial herbaceous plant with underground stem tubers rich in starch. It is demanding in water, the control of irrigation is at the base of the profitability of the culture in hot regions. From an agronomic point of view, its cultivation is easy and its yield potential is high, i.e. 20 to $30 \mathrm{t} / \mathrm{ha}$ [2]. Its culture is practiced in the dry and cold season, which allows a good tuberization of the plant because it needs a pronounced daily thermoperiod that is to say significant temperature variations between day and night, i.e. thermal amplitudes of $10^{\circ} \mathrm{C}$ to $15^{\circ} \mathrm{C}$ difference. The choice of suitable varieties and quality seeds, both resistant and healthy, is also essential to obtain a profitable crop. Indeed, crops grown from uncertified seeds have low or even minimal yields, and are more susceptible to diseases and insects throughout their growth, as well as after harvest.

Potato production in Senegal faces many difficulties related to the supply of quality seeds. Indeed, the production of vitrotubers is easily carried out and does not require any special infrastructure since the in vitro tuberization can be carried out in a dark culture chamber at room temperature of $19^{\circ} \mathrm{C}$ to $22^{\circ} \mathrm{C}$ and in 
media supplemented with high concentration of carbohydrates and a cytokinin. Vitrotubers have a quality advantage conferred by a production carried out in the laboratory, under aseptic conditions, without the possibility of external contamination [3] [4].

Potato microtubers (S. tuberosum L.) produced in vitro are currently used in many sectors of agriculture as research material but also as quality seeds [5]. Indeed, the microtuber is considered as one of the most effective means of spreading basic materials, as well as transporting and preserving potato germplasm. In practice, large microtubers are preferred because they are easy to handle and produce vigorous plants [6]. They are also less prone to drying out in storage, have a short dormancy period compared to larger conventional tubers and a high survival rate when transferred directly to the soil [7]. These microtubers can be used as seeds and can be easily transported from one country to another or even from one continent to another by air. Moreover, microtubers and minitubers as well are a possible alternative for the production of potato seeds and to overcome phytosanitary contaminations [3].

To make the "potato" sector more attractive in Senegal, it would be necessary to improve the performance of Family Farming Farms and the competitiveness of their products to help strengthen food security and improve the living conditions of farmers and producers. For this, it is possible to set up an improved and shortened field multiplication scheme that requires intensification of the production of pre-basic material from in vitro laboratory. This is possible in tropical areas and would be profitable for the production of local seeds because the cost of local labor is lower and would have a low impact on production costs.

Given its economic importance in the Senegalese agri-food sector, the tree potato varieties (Aida, Atlas and Odessa) developed in the North have been chosen. They have proven to be well-adapted to Senegalese agro-climatic conditions. Futhermore, they give a good yield per hectare to the field, with large tubers and present culinary qualities appreciated by local consumers. These varieties also exhibit good storage capacity over a long period.

The aim of this study was to examine the effect of microtuber size of three potato varieties, produced in vitro, on the yield and vigor of plants and minitubers resulting from the germination of these vitrotubers, under semi-controlled conditions.

\section{Material and Methods}

\subsection{Biological Material}

The plant material used represents the microtubers of the 3 potato varieties (Aida, Atlas and Odessa) harvested aseptically from different in vitro tuberization media [8] and kept in Petri dishes hermetically sealed with parafilm. They were stored in darkness, in a cold room at $4^{\circ} \mathrm{C} \pm 1^{\circ} \mathrm{C}$, for at least 3 months, a period which corresponds to dormancy.

The microtubers of each variety were previously sorted and classified into two sizes (less than $4 \mathrm{~mm}$ and greater than or equal to $4 \mathrm{~mm}$ ). Then, they were 
pre-germinated under diffused light at room temperature $\left(25^{\circ} \mathrm{C} \pm 1^{\circ} \mathrm{C}\right)$ for $2-3$ weeks.

The germinated microtubers were maintained at $25^{\circ} \mathrm{C} \pm 1^{\circ} \mathrm{C}$ for 3 weeks, at a physiological stage of "multiple sprouts", as previously described by [9], and were sown in black polyethylene bags. These ones were filled with a sterilized soil $\left(120^{\circ} \mathrm{C}, 2 \mathrm{~h}\right)$ aerated with perlite granules $(2 \mathrm{v} / \mathrm{v})$. They were incubated in a glasshouse and sown at the rate of one microtuber per bag and 30 per size and per variety. Watering is done every two days with tapwater. At the end of the plant's development cycle (3 - 4 months), one harvest was made per variety and per size (Table 1 ). The harvested minitubers were washed in deionized water, surface-wiped with blotting paper, weighed and then calibrated.

\subsection{Biomass Determination}

After 3 - 4 months of culture, the fresh and dry weight of the aerial and root parts (data not shown) and minitubers were measured. The parameters were evaluated (Table 1) using a Sartorius precision scale (accuracy: $0.0001 \mathrm{~g}$ ) for fresh and dry biomass determination. Following these measurements, each part was separated from each other. Then, these latter parts are dried in an oven (BINDER brand) for $72 \mathrm{~h}$ for the aerial parts and for 10 days for the minitubers samples at a temperature of $70^{\circ} \mathrm{C} \pm 0.5^{\circ} \mathrm{C}$. Then, the dry biomass of the aerial parts and the minitubers were weighed again, respectively.

\subsection{Statistical Analysis}

A statistical study comprising an analysis of the variance and the calculation of the mean, are carried out by the software SPSS version 17.0. The statistical analysis focused on the comparison of the different calibers using an analysis of variance (ANOVA) at a threshold of $5 \%$, followed by a comparison of the means (Student, Newman and Keuls's test). The results obtained are then represented in graphs using the EXCEL software.

\section{Results}

\subsection{Influence of Microtuber Size on the Vegetative Development}

By testing three varieties, we found that the vegetative development of plants from microtubers, with a size greater than $4 \mathrm{~mm}$, is more vigorous than that ones with a caliber less than $4 \mathrm{~mm}$, for all varieties. Thus, the fresh weight of the

Table 1. Agro-morphological traits characterized for the 3 varieties of potato maintained growing under shade for 3 - 4 months.

\begin{tabular}{|c|c|c|c|c|c|c|c|c|}
\hline \multirow{2}{*}{ Varieties } & \multirow{2}{*}{$\begin{array}{l}\text { Microtubers } \\
\text { sown } \\
\text { Size }<4 \mathrm{~mm}\end{array}$} & \multirow{2}{*}{$\begin{array}{c}\text { Microtubers } \\
\text { sown } \\
\text { Size } \geq 4 \mathrm{~mm}\end{array}$} & \multicolumn{6}{|c|}{ Agro-morphological parameters studied for each size of Microtubers sown } \\
\hline & & & \multirow{4}{*}{$\begin{array}{c}\text { Fresh } \\
\text { Biomass of } \\
\text { Aerial parts } \\
\quad \text { (g) }\end{array}$} & \multirow{4}{*}{$\begin{array}{l}\text { Dry Biomass } \\
\text { of Aerial } \\
\text { parts }(\mathrm{g})\end{array}$} & \multirow{4}{*}{$\begin{array}{c}\text { Number of } \\
\text { minitubers } \\
\text { collected/Variety }\end{array}$} & \multirow{4}{*}{$\begin{array}{l}\text { Average Size } \\
\text { of minitubers } \\
\qquad(\mathrm{mm})\end{array}$} & \multirow{4}{*}{$\begin{array}{l}\text { Average fresh weight } \\
\text { of minitubers } \\
\text { (g) }\end{array}$} & \multirow{4}{*}{$\begin{array}{l}\text { Dry Biomass } \\
\text { of minitubers } \\
\text { (g) }\end{array}$} \\
\hline Aida & 30 & 30 & & & & & & \\
\hline Atlas & 30 & 30 & & & & & & \\
\hline Odessa & 30 & 30 & & & & & & \\
\hline
\end{tabular}


aerial part of the plants resulting from microtubers, with a size greater than 4 $\mathrm{mm}$, is also higher (Figure 1, Plate 1 and Table 3). This result is more significant for the Ä̈da and Odessa varieties. However, in the Atlas variety, there is no significant difference between the plants obtained from these two weights.

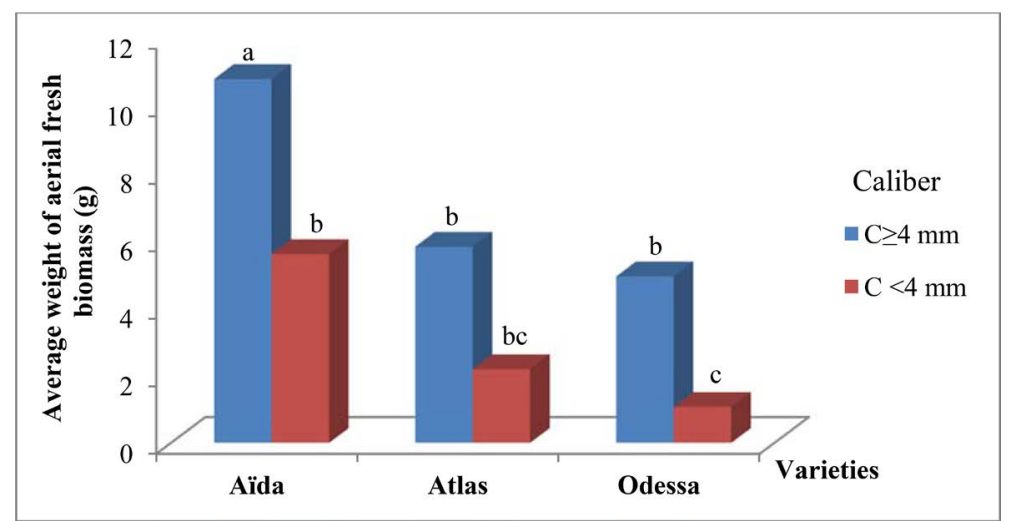

Figure 1. Effects of microtuber size on the vegetative development of plants of the Aïda, Atlas and Odessa varieties. For each variety and caliber, values followed by the same letter do not differ significantly at a p value of $5 \%$.
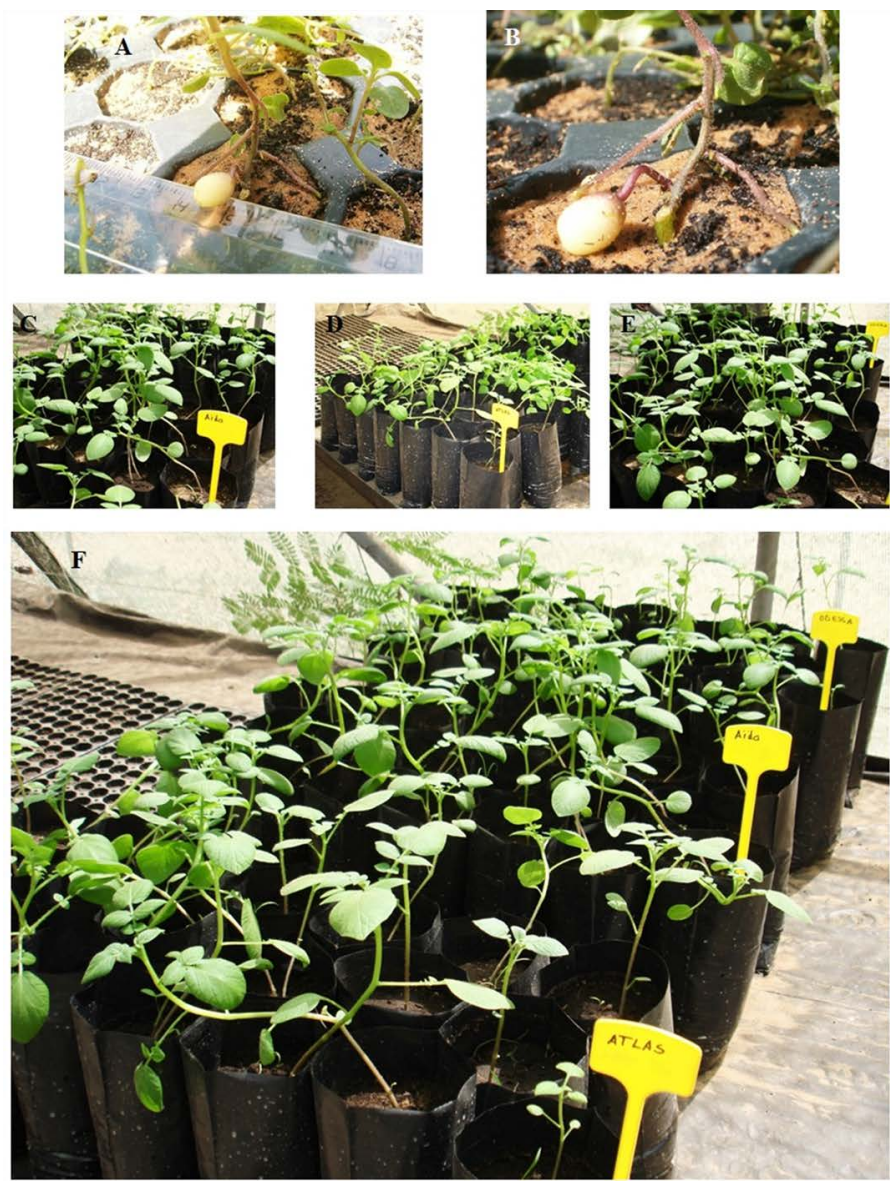

Plate 1. Morphological appearance of minitubers at the start of formation (A1, A2) in alveolar sowing trays and potato plants obtained from microtubers of 3 varieties $(B, C, D$ and F) sown in polyethylene bags and placed under shade, after 3 to 4 months of culture. 


\subsection{Influence of Microtuber Size on the Average Number of Minitubers}

The influence of the size of the microtubers on the yield of the plants obtained is examined. Thus, plants from microtubers, larger than $4 \mathrm{~mm}$ in size, gave a higher yield. The number of minitubers, harvested from plants grown from microtubers with a size greater than $4 \mathrm{~mm}$, for the Atlas, Ä̈da and Odessa varieties is, respectively equal to 18,32 and 16 minitubers. The ratio is also, respectively, equal to $1.8,3.5$ and 2 minitubers harvested per microtuber planted (Figure 2). However, for the Aida variety, the Student-Newman-Keuls test indicates that there is no significant difference in the yield of plants from microtubers larger or smaller than $4 \mathrm{~mm}$.

The yield of minituber plants also depends on the variety (Table 2). A higher yield was found in Aida (58 minitubers) than in other varieties (Plate 2). The following is Atlas variety (26) which, despite the lack of germination of two microtubers, had a higher yield than that of Odessa (23).

\subsection{Influence of Microtuber Size on the Average Weight of the Minitubers}

This study revealed that the average weight of minitubers harvested per plant is higher in plants produced from microtubers with a size greater than $4 \mathrm{~mm}$ for all varieties (Figure 3 and Table 3). This weight is not significantly different for all

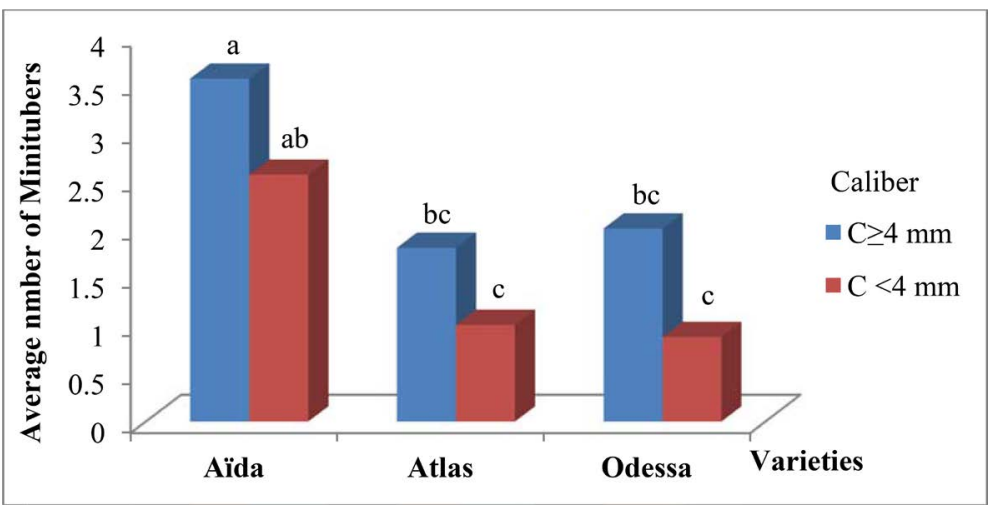

Figure 2. Effects of microtuber size on the mean number of minitubers of the Ä̈da, Atlas and Odessa varieties. For each variety and caliber, values followed by the same letter do not differ significantly at a $\mathrm{p}$ value of $5 \%$.

Table 2. Number of minitubers harvested per size and variety.

\begin{tabular}{cccc}
\hline & \multicolumn{2}{c}{ Number of minitubers per Size } & Total \\
\cline { 2 - 3 } & $\geq \mathbf{4 m}$ & $<\mathbf{m m}$ & \\
\hline Varieties & 32 & & \\
Ä̈da & 18 & 26 & 58 \\
Atlas & 16 & 8 & 26 \\
Odessa & & 7 & 23 \\
\hline
\end{tabular}




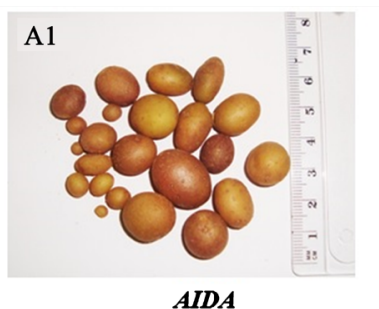

(From Microtuber, caliber $<4 \mathrm{~mm}$ )

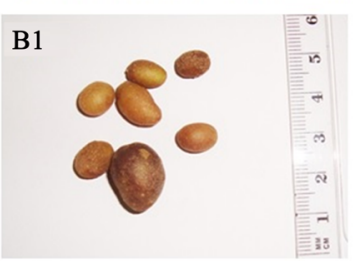

ATLAS

(From Microtuber, caliber $<4 \mathrm{~mm}$ )

C1

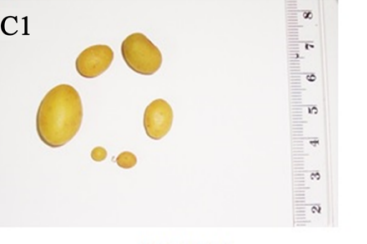

ODESSA

(From Microtuber, caliber $<4 \mathrm{~mm}$ )

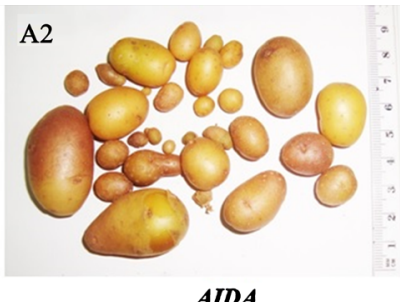

(From Microtuber, caliber $\geq 4 \mathrm{~mm}$ )

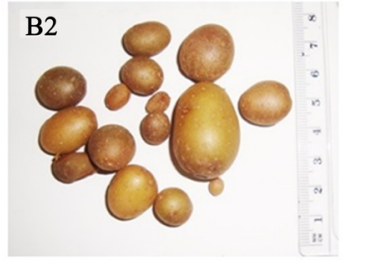

ATLAS

(From Microtuber, caliber $\geq 4 \mathrm{~mm}$ )

C2

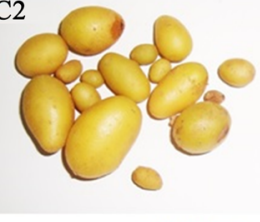

ODESSA

(From Microtuber, caliber $\geq 4 \mathrm{~mm}$ )

Plate 2. Morphological appearance of minitubers of the three potato varieties (Aida, Atlas, Odessa) harvested from plants, at the end of the development cycle, and issued from microtubers of size $<4 \mathrm{~mm}$ and $\geq 4 \mathrm{~mm}(\mathrm{~A} 2, \mathrm{~B} 2, \mathrm{C} 2)$.

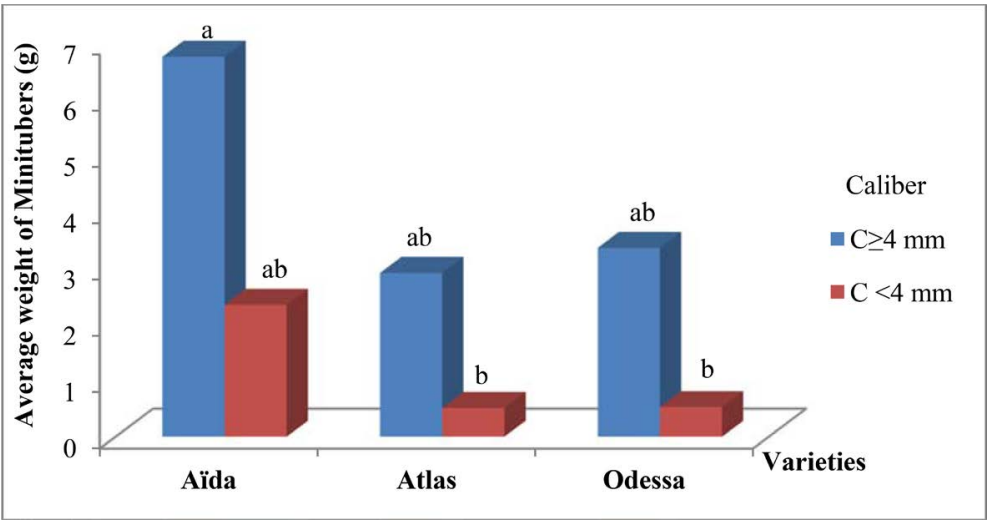

Figure 3. Effects of microtuber size on the fresh biomass of the harvested minitubers. For each variety and caliber, values followed by the same letter do not differ significantly at a $\mathrm{p}$ value of $5 \%$.

varieties. Within each variety, there is no significant difference between the average weights of the minitubers from plants of the two sizes. However, the Aida variety appeared to be the best as it gave the highest average weight per plant.

\subsection{Effects of Microtuber Size on the Average Size of the Minitubers}

The experiment revealed that for all varieties, the average minituber size of 
plants, from microtubers larger than $4 \mathrm{~mm}$, is higher than that of minitubers from plants grown from microtubers smaller than $4 \mathrm{~mm}$. The average size of minitubers of the Odessa variety is bigger than that of other varieties. However, this size is not significantly different from other varieties according to the Student-Newman-Keuls test. For the minitubers of plants produced from microtubers, with a caliber less than $4 \mathrm{~mm}$, the variety Aida produced the larger minitubers. However, this result, as previously, is not significantly different from that of the other varieties (Figure 4 and Table 3 ).

\subsection{Effects of Microtuber Size on the Above-Ground Dry Biomass}

The Student-Newman-Keuls's test revealed that the above-ground dry biomass of these three varieties depends on the size of the microtubers sown. Thus, plants from microtubers, with a size greater than $4 \mathrm{~mm}$, gave a higher dry biomass comparatively to plants produced from microtubers, with a size less than $4 \mathrm{~mm}$. The Aida variety, with a higher yield in number of minitubers formed (32), gave a higher dry biomass than that of other varieties for the same size. This result is

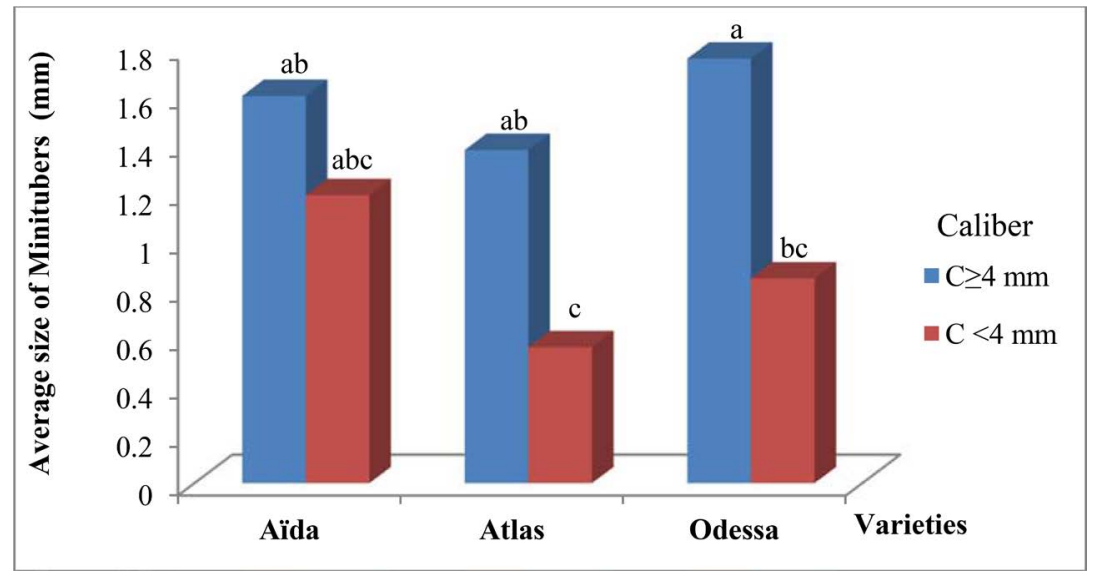

Figure 4. Effects of microtuber size on the average size of harvested minitubers. For each variety and caliber, values followed by the same letter do not differ significantly at a $\mathrm{p}$ value of $5 \%$.

Table 3. Effects of microtuber size on the yield of the plants under semi-axenic conditions.

\begin{tabular}{|c|c|c|c|c|c|c|c|}
\hline \multirow[b]{2}{*}{ Varieties } & \multirow[b]{2}{*}{ Size (mm) } & \multicolumn{6}{|c|}{ Yield of plants from microtubers } \\
\hline & & $\begin{array}{c}\text { Fresh Biomass of } \\
\text { Aerial parts (g) }\end{array}$ & $\begin{array}{l}\text { Dry Biomass of } \\
\text { Aerial parts (g) }\end{array}$ & Ratio & $\begin{array}{l}\text { Average weight of } \\
\text { minitubers }(\mathrm{g})\end{array}$ & $\begin{array}{c}\text { Mean Size of } \\
\text { minitubers }(\mathrm{mm})\end{array}$ & $\begin{array}{l}\text { Dry Biomass of } \\
\text { minitubers (g) }\end{array}$ \\
\hline \multirow{2}{*}{ Ä̈da } & $\mathrm{C}<4$ & $5.61^{\mathrm{b}}$ & $0.94^{\mathrm{b}}$ & $2.55^{\mathrm{ab}}$ & $2.355^{\mathrm{ab}}$ & $11.9^{\mathrm{abc}}$ & $0.31^{\mathrm{b}}$ \\
\hline & $C \geq 4$ & $10.78^{\mathrm{a}}$ & $1.69^{\mathrm{a}}$ & $3.55^{\mathrm{a}}$ & $6.749^{\mathrm{a}}$ & $16.1^{\mathrm{ab}}$ & $0.82^{\mathrm{a}}$ \\
\hline \multirow[t]{2}{*}{ Atlas } & $\mathrm{C}<4$ & $2.21^{\mathrm{bc}}$ & $0.29^{c}$ & $1^{\mathrm{c}}$ & $0.514^{\mathrm{b}}$ & $5.7^{\mathrm{c}}$ & $0.08^{\mathrm{c}}$ \\
\hline & $C \geq 4$ & $5.83^{\mathrm{b}}$ & $0.86^{\mathrm{b}}$ & $1.8^{\mathrm{bc}}$ & $2.912^{\mathrm{ab}}$ & $13.8^{\mathrm{abc}}$ & $0.45^{\mathrm{b}}$ \\
\hline \multirow{2}{*}{ Odessa } & $\mathrm{C}<4$ & $1.07^{\mathrm{c}}$ & $0.24^{c}$ & $0.87^{\mathrm{c}}$ & $0.531^{\mathrm{b}}$ & $8.5^{\mathrm{bc}}$ & $0.06^{\mathrm{c}}$ \\
\hline & $C \geq 4$ & $4.95^{\mathrm{b}}$ & $0.82^{\mathrm{b}}$ & $2^{\mathrm{bc}}$ & $3.364^{\mathrm{b}}$ & $17.6^{\mathrm{a}}$ & $0.38^{\mathrm{b}}$ \\
\hline
\end{tabular}

Ratio: Number of minitubers per plant; For each variety, values in the same column followed by the same letter do not differ significantly at $5 \%$ level. 
significantly different from that of the other varieties. Atlas and Odessa varieties have the same behavior with respect to biomass. So, they were not significantly different (Figure 5 and Table 3).

\subsection{Effects of Microtuber Size on the Dry Biomass of the Minitubers}

The dry biomass of the minitubers of plants derived from microtubers, with a size greater than $4 \mathrm{~mm}$, is higher than that of the minitubers of plants from microtubers with a caliber less than $4 \mathrm{~mm}$, for all varieties (Figure 6 and Table 3). The minitubers harvested from the Aida variety plants resulting from the microtubers, with a size greater than $4 \mathrm{~mm}$, gave the highest dry biomass with $0.82 \mathrm{~g}$. The latter is significantly different from that of all other varieties. The dry biomass of minitubers collected from plants, derived from microtubers smaller than $4 \mathrm{~mm}$ in size, was not significantly different for all varieties.

\section{Discussion}

Our results clearly established that vegetative development of plants, diameter,

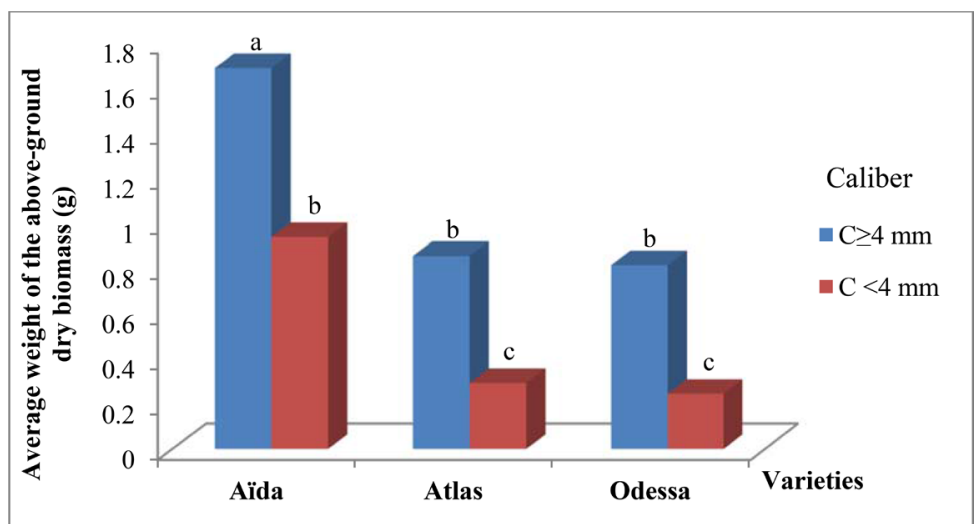

Figure 5. Effects of microtuber size on the above-ground dry biomass. For each variety and caliber, values followed by the same letter do not differ significantly at a $\mathrm{p}$ value of $5 \%$.

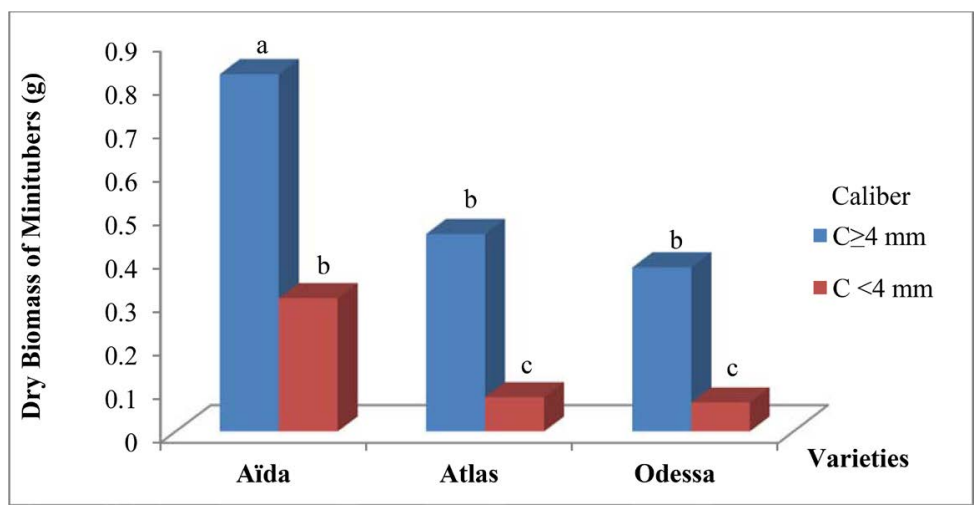

Figure 6. Effects of microtuber size on the dry biomass of the harvested minitubers. For each variety and caliber, values followed by the same letter do not differ significantly at a $\mathrm{p}$ value of $5 \%$. 
weight and number of minitubers harvested in the greenhouse are influenced by the size of the microtubers sown.

\subsection{Effects of Microtuber Size on Vegetative Development}

The vegetative development of plants is influenced by the size of the microtubers planted but also by the genotype. Indeed, the larger the size of the microtuber, the more the plant resulting from the latter has a vigorous vegetative development. Thus, for all varieties, plants produced from microtubers, with a size greater than $4 \mathrm{~mm}$, are more vigorous than those from microtubers with a size less than $4 \mathrm{~mm}$. Thus, the larger the diameter of the microtubers planted, the greater the yield. It, thus, emerges that the size effect responsible for a large variation in the yield is a consequence of the physiological state of the microtubers at the time of planting. In addition, the size of microtubers also positively influences their germination capacity and vigor. Therefore, the yield of plants is dependent to these factors.

This result can be explained by the amount of reserves contained in the microtuber and intended for the development of germs but also of the future plant. Indeed, the more the size of the microtubers increases, the more the quantity of carbohydrate reserves is important and is beneficial to the vegetative development of the plants and to the yield.

However, for microtubers, with a size greater than $10 \mathrm{~mm}$, we notice the opposite, namely that the germination capacity is lower as for the classic tubers for which, it is known that those of large sizes have a reduced germination capacity and a vigorous less important plants. This negatively influences the yield of the plants and the number of sprouts that develop after the dormant period. The size of microtubers, therefore, has a significant importance and influence on their physiological and agronomic characteristics [10].

This study confirms previous works carried out by [6] and [10] who show that large microtubers produce vigorous plants. However, plants of the Aida variety are much more vigorous than those of other varieties. This remark confirms that vegetative development is also a function of the genotype.

\subsection{Effects of Microtuber Size on the Average Number of Minitubers}

The production of potato minitubers is the classic intermediate step in making possible the field use of the plant material originated from in vitro tissue culture. The techniques used for the production of minitubers are diverse but are most often based on the transplanting of vitroplants or in vitro cuttings in a disinfected organic substrate or not. In this study, a production of minitubers of superior sanitary quality has been considered using pre-germinated microtubers obtained previously under axenic conditions.

The vegetative development of the plants has a consequence on the minituber yield because we obtained, in the Aïda variety, an average number of 3.55 minitubers harvested per plant from microtubers with a size greater than $4 \mathrm{~mm}$ compared 
to 2.55 for those from microtubers with a size less than $4 \mathrm{~mm}$. For Atlas and Odessa varieties, plants from microtubers, with a size greater than $4 \mathrm{~mm}$, have a higher ratio than plants from small sizes. Thus, Atlas and Odessa respectively gave a ratio of 1.8 and 2 for diameters greater than $4 \mathrm{~mm}$ against 1 and 0.875 for smaller diameters. These facts corroborate the results of [11] which explain that the larger the diameter of the microtubers planted, the greater the number of minitubers harvested per plant. These results do not seem valid in the case of classic tubers of larger size. Indeed, [12] have demonstrated that plants produced from small tubers $(12.5 \pm 2.5 \mathrm{~g})$ generally produce more stems and tubers and give a better yield than large tubers $(37 \pm 2.5 \mathrm{~g})$ for an equivalent planting density.

\subsection{Effects of Microtuber Size on the Weight and Average Size of the Minitubers}

The influence of the size of the microtubers planted on the weight and size of the minitubers harvested is demonstrated. In the Ä̈da variety, we obtained an average weight and an average size of higher minitubers in plants produced from microtubers, with a size greater than $4 \mathrm{~mm}$. These same observations were made with the Altas and Odessa varieties. The study of [13] confirms these results, by showing a positive correlation between the vigor of cultivated plants and the size of the minitubers harvested. Indeed, the most vigorous plants produce more homogeneous minitubers with a size greater than $5 \mathrm{~mm}$. According to [11], the size effect responsible for a large variation in yield, can be explained by the physiological state of the material at the time of planting. Indeed, [10] have demonstrated that the duration of dormancy is correlated with the size of the microtubers. In the same way, the germination vigor is modified and the final yield is dependent on the size. In fact, when the diameter of the microtubers increases, the pool of reserves, in particular carbohydrates, is greater and could thus be more favorable to the development of the plant and to the final yield in minitubers produced [11].

\subsection{Influence of Microtuber Size on the Above-Ground Parts and the Minituber Dry biomass}

During the tests under semi-controlled conditions, we were able to verify importance of the size of the microtubers sown on the above-ground dry biomass. There is a correlation between vegetative development of plants and dry biomass. Indeed, the plants resulting from microtubers, with a size greater than $4 \mathrm{~mm}$ and having a significant vegetative development, have a higher dry biomass. This result can be explained by the pool of reserves contained in the large-caliber microtubers, allowing the harmonious development of the plants. This development is also a function of photosynthesis which allows the production of organic substances necessary for plant growth. Minitubers are potato tubers obtained from tissue culture plants or vitrotubers under controlled condition. Plants, grown from the large caliber microtubers, gave higher dry biomass of the 
minitubers. This result is explained by the vigor of plants from this caliber. According to [14], the enrichment of the in vitro nutrient solution in phosphorus induces an increase in the number of minitubers produced later with a size greater than $15 \mathrm{~mm}$ ( $>5 \mathrm{~g}$ ). Likewise, a basic nutrient medium containing 100 $\mathrm{mM}$ of nitrogen in the form of Ammonium nitrate $\left(\mathrm{NH}_{4} \mathrm{NO}_{3}\right)$ allows tubers to grow better [15]. We can assume that the large caliber contains important nutrients that affect the dry biomass of harvested minitubers.

\section{Conclusions}

True potato seeds are botanical seeds used in seedlings for growing potatoes. It is an alternative to the use of seedlings, often incorrectly called "seeds", which is of economic interest in hot tropical regions where the cost of supplying quality seedlings is a limiting factor in potato production. The disadvantages of true potato seeds are linked to the genetic variability which tends to produce tubers of heterogeneous quality, the cultivated varieties of potatoes having a very high degree of heterozygosity. Another alternative to the use of imported seeds is to produce minitubers under semi-axenic conditions (under shade) from microtubers produced in vitro. Since, the production of potato minitubers is the classic intermediate step in making possible the field use of the plant material originated from in vitro tissue culture.

The size effects of the microtubers sown on the yield of the plants result in an increase in the ratio, in the vegetative development of the plants, but also in the number and size of the minitubers harvested. Thus, plants produced from microtubers, with a size greater than $4 \mathrm{~mm}$, were more vigorous and produced minitubers with a higher number, average weight, size and dry biomass than those from plants produced from microtubers with a size less than $4 \mathrm{~mm}$.

The use of microtubers as seeds requires that the size be large to avoid drying out, but above all, to increase the yield of the plants that will be produced there.

\section{Acknowledgements}

The authors are grateful to Prof Adams Tidjani for proofreading the manuscript in English version.

\section{Conflicts of Interest}

The authors declare no conflicts of interest regarding the publication of this paper.

\section{References}

[1] PANA (2006) Plan d'action national pour l'adaptation au changement climatique. Ministère de l'environnement et de la protection de la nature, Sénégal, 84 p.

[2] Food and Agriculture Organization Corporate Statistical Database (2007) Site de la FAO de statistiques. http://faostat.fao.org/

[3] Charles, G., Rossignol, L. and Rossignol, M. (1995) Applications d'un modèle de 
développement et de tubérisation synchrones chez la pomme de terre cultivée in Vitro. Evolution d'activités enzymatiques. Acta Botanica Gallica, 142, 321-331. https://doi.org/10.1080/12538078.1995.10515249

[4] Lê, C.L. (1995) Applications de la microtubérisation in Vitro chez différentes variétés de pomme de terre. Acta Botanica Gallica, 142, 389. https://doi.org/10.1080/12538078.1995.10515259

[5] Coleman, W.K., Donnelly, D.J. and Coleman, S.E. (2001) Potato Microtubers as Research Tools: A Review. American Journal of Potato Research, 78, Article No. 47. https://doi.org/10.1007/BF02874824

[6] Wiersema, S.G., Cabello, R., Tovar, P. and Dodds, J.H. (1987) Rapid Seed Multiplication by Planting into Beds Micro Tubers and in Vitro Plants. Potato Research, 30, 117-120. https://doi.org/10.1007/BF02357690

[7] Leclerc, Y., Donnelly, D.J. and Seabrook, J.E.A. (1994) Microtuberization of Layered Shoots and Cuttings of Potato: The Influence of Growth Regulators and Incubation Periods. Plant Cell, Tissue and Organ Culture, 37, 113-120. https://doi.org/10.1007/BF00043604

[8] Diémé, A., Sagna, M. and Sy, M.O. (2011) Influence of Hormonal Treatments and of Sucrose on the Microtuberization of Three Potato Varieties (Solanum tuberosum L.) Adapted to Agroclimatic Conditions in Senegal). International Journal of Plant, Animal and Environmental Sciences, 1, 69-77.

[9] Diémé, A. and Sy, M.O. (2013) Environmental, Morphological and Physiological Factors Analyzes for Optimization of Potato (Solanum tuberosum L.) Microtuber in Vitro Germination. Advances in Bioscience and Biotechnology, 4, 986-992. https://doi.org/10.4236/abb.2013.411131

[10] Désiré, S., Couillerot, J.P., Hilbert, J.L. and Vasseur, J. (1995) Dormance et germination des microtubercules de pomme de terre (Solanum tuberosum L.) produit in Vitro: Effets de la concentration en saccharose du milieu de tubérisation, de la durée de conservation à $4^{\circ} \mathrm{C}$ et d'un traitement avec de l'acide gibbérellique. Acta Botanica Gallica, 142, 371-378. https://doi.org/10.1080/12538078.1995.10515257

[11] Désiré, S., Couillerot, J.P., Hilbert, J.L. and Vasseur, J. (1995) Protein Changes in Solanum tuberosum during in Vitro Tuberization of Nodal Cuttings. Plant Physiology \& Biochemistry, 33, 303-310. https://hal.inrae.fr/hal-02705219

[12] O’Brien, P.J. and Allen, E.J. (1992) Effects of Seed Crop Husbandry, Seed Source, Seed Tuber Weight and Seed Rate on the Growth of Ware Potato Crops. The Journal of Agricultural Science, 119, 355-366. https://doi.org/10.1017/S0021859600012193

[13] Lakhoua, L. and Ellouze, O. (1990) Induction de la microtubérisation chez Solanum tuberosum variété: Spunta. Cinquantenaire de la culture in Vitro Versailles (France). Les colloques de IINRA, 12, 279-281.

[14] Rolot, J.L., Seutin, H. and Michelante, D. (2002) Production de minitubercules de pomme de terre par hydroponie: Evaluation d'un système combinant les techniques "NFT" et "Gravel Culture" pour deux types de solutions nutritives. Biotechnologie, Agronomie, Société et Environnement, 6, 155-161.

[15] Lê, C.L. and Thomas, D. (2009) Production de microtubercules de pomme de terre in vitro: effet de la durée de culture. Revue Suisse Agriculture, 41, 289-293. 